\title{
FORTY-SIXTH ANNUAL LIST OF PAPERS
}

READ BEFORE THE AMERICAN MATHEMATICAL SOCIETY AND SUBSEQUENTLY PUBLISHED, INCLUDING REFERENCE TO THE PLACES OF PUBLICATION

Adams, C. R., and Morse, A. P. On the space (BV). Read Dec. 29, 1936. Transactions of this Society, vol. 42, No. 2 (Sept., 1937), pp. 194-205.

Adkisson, V. W. Finite groups associated with certain cyclic curves. Read Jan. 1, 1936. Comptes Rendus des Séances de la Société des Sciences et des Lettres de Varsovie, Classe III, vol. 29 (1936), pp. 23-26.

Adkisson, V. W., and MacLane, Saunders. On planar graphs whose homeomorphisms can all be extended for any mapping on the sphere. Read Dec. 30, 1936. American Journal of Mathematics, vol. 59, No. 10 (Oct., 1937), pp. 823-832.

Agnew, R. P. Generalizations of the Riemann-Lebesgue theorem. I. Read Sept. 10, 1935. Tôhoku Mathematical Journal, vol. 42, No. 2 (Dec., 1936), pp. 300-310.

On the existence of linear functionals defined over linear spaces. Read Sept. 8, 1937. This Bulletin, vol. 43, No. 12 (Dec., 1937), pp. 868-872.

Ahlfors, L. V. On Phragmén-Lindelöf's principle. Read April 10, 1936. Transactions of this Society, vol. 41, No. 1 (Jan., 1937), pp. 1-8.

Akeley, E. S. Tensors associated with a pair of quadratic differential forms. Read April 11, 1936. Journal of the Franklin Institute, vol. 223, No. 1334 (Feb., 1937), pp. 199-214.

Albert, A. A. A note on the matrices defining total real fields. Read Dec. 31, 1936. This Bulletin, vol. 43, No. 4 (April, 1937), pp. 242-244.

- Normalized integral bases of algebraic number fields. I. Read Dec. 31, 1936. Annals of Mathematics, (2), vol. 38, No. 4 (Oct., 1937), pp. 923-957.

- p-algebras over a field generated by one indeterminate. Read Sept. 8, 1937. This Bulletin, vol. 43, No. 10 (Oct., 1937), pp. 733-736.

Allendoerfer, C. B. Einstein spaces of class one. Read Sept. 3, 1936. This Bulletin, vol. 43, No. 4 (April, 1937), pp. 265-270.

— The imbedding of Riemann spaces in the large. Read Dec. 29, 1936. Duke Mathematical Journal, vol. 3, No. 2 (June, 1937), pp. 317-333.

Archibald, R. G. Highly composite ideals. Read Jan. 2, 1936. Transactions of the Royal Society of Canada, (3), Section III, vol. 30 (1936), pp. 41-47.

Baer, Reinhold. Primary abelian groups and their automorphisms. Read Oct. 31, 1936. American Journal of Mathematics, vol. 59, No. 1 (Jan., 1937), pp. 99-117.

—Dualism in abelian groups. Read Oct. 31, 1936. This Bulletin, vol. 43, No. 2 (Feb., 1937), pp. 121-124.

- Abelian groups without elements of finite order. Read Sept. 1, 1936. Duke Mathematical Journal, vol. 3, No. 1 (March, 1937), pp. 68-122.

Equivalence of algebraic extensions. Read Oct. 31, 1936. This Bulletin, vol. 43, No. 6 (June, 1937), pp. 432-437.

- Abelian fields and duality of abelian groups. Read Sept. 10, 1937. American Journal of Mathematics, vol. 59, No. 4 (Oct., 1937), pp. 845-868.

Ballou, D. H. Functions representable by two Laplace integrals. Read Sept. 1, 
1936. Duke Mathematical Journal, vol. 2, No. 4 (Dec., 1936), pp. 722-732. Basoco, M. A. On certain systems of polynomials. Read Nov. 30, 1934. Tôhoku Mathematical Journal, vol. 43, No. 1 (March, 1937), pp. 109-121.

Beckenbach, E. F. Convex functions. Read April 11, 1936. This Bulletin, vol. 43, No. 6 (June, 1937), pp. 363-371.

Bell, Clifford. On a theorem in higher plane curves. Read Feb. 29, 1936. Mathematical Gazette, vol. 20, No. 239 (July, 1936), pp. 186-187.

On a determinant function involving the parameter of a plane curve. Read Nov. 30, 1935. American Mathematical Monthly, vol. 44, No. 4 (April, 1937), pp. 218-221.

Bell, E. T. Note on an inversion formula. Read April 11, 1936. American Mathematical Monthly, vol. 43, No. 8 (Oct., 1936), pp. 464-465.

- General theorems on numerical functions. Read Nov. 30, 1935. Journal de Mathématiques Pures et Appliquées, vol. 16, No. 2 (Feb., 1937), pp. 151154.

- Certain ternary cubic arithmetical forms. Read Nov. 28, 1936. Duke Mathematical Journal, vol. 3, No. 2 (June, 1937), pp. 289-293.

- Representations in certain pure forms of degrees higher than the second. Read April 3, 1937. American Journal of Mathematics, vol. 59, No. 3 (July, 1937), pp. 585-598.

Bird, M. T. On a classification of integral functions by means of certain invariant point properties. A supplement. Read Sept. 10, 1937. Transactions of this Society, vol. 42, No. 2 (Sept., 1937), pp. 191-193.

Birkhoff, Garrett. A note on topological groups. Read Jan. 2, 1936. Compositio Mathematica, vol. 3, No. 4 (Dec., 1936), pp. 427-430.

- Continuous groups and linear spaces. Read Feb. 23, April 19 and Sept. 10, 1935. Recueil Mathématique, vol. 1 (1936), pp. 635-642.

Moore-Smith convergence in general topology. Read Feb. 29, 1936. Annals of Mathematics, (2), vol. 38, No. 1 (Jan., 1937), pp. 57-60.

On the integration of operators. Read Dec. 30, 1936. Proceedings of the National Academy of Sciences, vol. 23, No. 1 (Jan., 1937), pp. 11-13.

- Representability of Lie algebras and Lie groups by matrices. Read Sept. 5, 1936. Annals of Mathematics, (2), vol. 38, No. 2 (April, 1937), pp. 526532.

Rings of sets. Read Sept. 5, 1936. Duke Mathematical Journal, vol. 3, No. 3 (Sept., 1937), pp. 443-454.

Black, Amos. See Davis, H. A.

Blumenthal, L. M. The geometry of a class of semi-metric spaces. Read Nov. 28, 1936. Tôhoku Mathematical Journal, vol. 43, No. 1 (March, 1937), pp. 205-224.

Bochner, Salomon, and Martin, W. T. Singularities of composite functions in several variables. Read Feb. 29, 1936. Annals of Mathematics, (2), vol. 38, No. 2 (April, 1937), pp. 293-302.

Boggs, Herbert, and Rainich, G. Y. Note on group postulates. Read April 10, 1936. This Bulletin, vol. 43, No. 2 (Feb., 1937), pp. 81-84.

Bourgin, D. G. Interference calculations and wave groups. Read Jan. 2, 1936. Philosophical Magazine, (7), vol. 21, No. 144 (June, 1936), pp. 1033-1056.

Bourgin, D. G., and Duffin, R. J. The Heaviside operational calculus. Read 
Nov. 28, 1936. American Journal of Mathematics, vol. 59, No. 3 (July, 1937), pp. 489-505.

Bower, J. W. The problem of Lagrange with finite side conditions. Read June 19, 1933. Contributions to the Calculus of Variations, 1933-37, University of Chicago, pp. 1-51.

Brauer, Richard. On algebras which are connected with the semi-simple continuous groups. Read Sept. 1, 1936. Annals of Mathematics, vol. 38, No. 4 (Oct., 1937), pp. 857-872.

Brown, A. B. Critical curvatures in Riemannian spaces. Read March 26 and 27, 1937. Duke Mathematical Journal, vol. 3, No. 3 (Sept., 1937), pp. 473483.

Browne, E. T. Sets of conjugate matrices. Read Sept. 10, 1937. American Journal of Mathematics, vol. 59, No. 4 (Oct., 1937), pp. 845-868.

Camp, B. H. Methods of obtaining probability distributions. Read April 10, 1936. Annals of Mathematical Statistics, vol. 8, No. 2 (June, 1937), pp. 90-102.

Camp, C. C. A generalization of Chevilliet's formula. Read Nov. 30, 1934. National Mathematics Magazine, vol. 11, No. 1 (Oct., 1936), pp. 8-13.

Note on numerical evaluation of double series. Read Nov. 30, 1934. Annals of Mathematical Statistics, vol. 8, No. 1 (March, 1937), pp. 72-75.

Campbell, A. D. Pseudo-covariants of n-ics in a Galois field. Read Feb. 23, 1935. Tôhoku Mathematical Journal, vol. 43, No. 1 (March, 1937), pp. 17-29.

Carathéodory, Constantin. A generalization of Schwarz's lemma. Read Nov. 27, 1936. This Bulletin, vol. 43, No. 4 (April, 1937), pp. 231-241.

Carlitz, Leonard. On certain arithmetic functions of several arguments. Read Feb. 29, 1936. This Bulletin, vol. 43, No. 2 (Feb., 1937), pp. 109-114.

- Sums of squares of polynomials. Read Sept. 13, 1935. Duke Mathematical Journal, vol. 3, No. 1 (March, 1937), pp. 1-7.

- An arithmetic function. Read March 25, 1932. This Bulletin, vol. 43, No. 4 (April, 1937), pp. 271-276.

- Some formulas for factorable polynomials in several indeterminates. Read Dec. 31, 1936. This Bulletin, vol. 43, No. 4 (April, 1937), pp. 299-304.

- Criteria for certain higher congruences. Read Dec. 31, 1936. American Journal of Mathematics, vol. 59, No. 3 (July, 1937), pp. 618-628.

- An analogue of the von Staudt-Clausen theorem. Read Sept. 7, 1937. Duke Mathematical Journal, vol. 3, No. 3 (Sept., 1937), pp. 503-517.

Carmichael, R. D. On numbers of the form $a^{2}+a b^{2}$. Read April 11, 1936. American Mathematical Monthly, vol. 44, No. 2 (Feb., 1937), pp. 81-86.

Carroll-Rusk, E. See Snyder, Virgil.

Cartan, E. J. L'extension du calcul tensoriel aux géométries non-affines. Read Sept. 1, 1936. Annals of Mathematics, (2), vol. 38, No. 1 (Jan., 1937), pp. $1-13$.

Chanler, J. H. The involution curve determined from a special pencil of n-ics. Read Dec. 31, 1936. Transactions of this Society, vol. 42, No. 1 (July, 1937), pp. 1-15.

Church, Alonzo, and Kleene, S. C. Formal definitions in the theory of ordinal numbers. Read Sept. 1, 1936. Fundamenta Mathematicae, vol. 28 (1937), pp. 11-21.

Churchill, R.V. The inversion of the Laplace transformation by a direct expansion 
in series and its application to boundary-value problems. Read Sept. 5, 1936. Mathematische Zeitschrift, vol. 42, No. 4 (April, 1937), pp. 567-579.

The solution of linear boundary-value problems in physics by means of the Laplace transformation. I: A theory for establishing a solution in the form of an integral, for problems with vanishing initial conditions. Read April 9, 1937. Mathematische Annalen, vol. 114, No. 4 (July, 1937), pp. 591-613.

Clarkson, J. M. An involutorial line transformation determined by a congruence of twisted cubic curves. Read Dec. 27, 1934. This Bulletin, vol. 43, No. 2 (Feb., 1937), pp. 142-144.

Claytor, W. S. Peanian continua not imbeddable in a spherical surface. Read Dec. 30, 1936. Annals of Mathematics, (2), vol. 38, No. 3 (July, 1937), pp. 631-646.

Comenetz, George. See Kasner, Edward.

Cope, T. F. An analogue of Jacobi's condition for the problem of Mayer with variable end points. Read April 7, 1928. American Journal of Mathematics, vol. 59, No. 3 (July, 1937), pp. 655-672.

Copeland, A. H. A new definition of a Stieltjes integral. Read Dec. 31, 1930. This Bulletin, vol. 43, No. 8 (Aug., 1937), pp. 581-588.

Consistency of the conditions determining Kollektivs. Read June 22, 1933. Transactions of this Society, vol. 42, No. 3 (Nov., 1937), pp. 333-357.

Craig, H. V. On tensors relative to the extended point transformation. Read Sept. 10, 1937. American Journal of Mathematics, vol. 59, No. 4 (Oct., 1937), pp. 764-774.

Curry, H. B. On the use of dots as brackets in logical expressions. Read Dec. 31, 1936. Journal of Symbolic Logic, vol. 2, No. 1 (March, 1937), pp. 26-28.

Curtiss, J. H. A note on the Cesàro method of summation. Read Sept. 9, 1937. This Bulletin, vol. 43, No. 10 (Oct., 1937), pp. 703-708.

Daly, J. F. On those points of an algebraic manifold not reachable by a given parametric representation. Read Dec. 29, 1936. American Journal of Mathematics, vol. 59, No. 2 (April, 1937), pp. 359-362.

Davis, H. A., and Black, Amos. Some non-involutorial space transformations associated with pencils of nodal cubic surfaces. Read Sept. 13, 1935. Tôhoku Mathematical Journal, vol. 42, No. 2 (Dec., 1936), pp. 366-371.

Dodd, E. L. Internal and external means arising from the scaling of frequency functions. Read Feb. 20, 1937. Annals of Mathematical Statistics, vol. 8, No. 1 (March, 1937), pp. 12-20.

- Regression coefficients as means of certain ratios. Read March 27, 1937. American Mathematical Monthly, vol. 44, No. 5 (May, 1937), pp. 306308.

Doob, J. L. Stochastic processes depending on a continuous parameter. Read Sept. 1, 1936. Transactions of this Society, vol. 42, No. 1 (July, 1937), pp. 107-140.

Doole, H. P. Integration of certain simple step functions. Read April 11, 1936. American Mathematical Monthly, vol. 44, No. 4 (April, 1937), pp. 222227.

Dressel, F. G. A note on Young-Stieltjes integrals. Read Nov. 30, 1935. This Bulletin, vol. 43, No. 6 (June, 1937), pp. 377-378. 
Dribin, D. M. Quartic fields with the symmetric group. Read Dec. 29, 1936 . Annals of Mathematics, (2), vol. 38, No. 3 (July, 1937), pp. 739-749.

Duffin, R. J. See Bourgin, D. G.

Duren, W. L. A problem of Zermelo in the calculus of variations. Read Sept. 1, 1936. Duke Mathematical Journal, vol. 2, No. 4 (Dec., 1936), pp. 733-744.

Dwyer, W. A. On certain fundamental identities due to Uspensky. Read April 10, 1937. American Journal of Mathematics, vol. 59, No. 2 (April, 1937), pp. 290-294.

Dye, L. A. An involutorial transformation determined by three pencils of planes. Read April 11, 1936. Tôhoku Mathematical Journal, vol. 43, No. 1 (March, 1937), pp. 174-177.

- A transformation associated with the trisecants of a rational twisted quintic curve. Read Dec. 29, 1936. This Bulletin, vol. 43, No. 10 (Oct., 1937), pp. 719-723.

Three involutorial transformations associated with a ruled quartic surface with a double twisted cubic curve. Read Feb. 29, 1936. Bulletin of The Citadel, vol. 1, No. 4 (Nov., 1937), pp. 38-43.

Eddington, A. S. The cosmical constant and the recession of the nebulae. Read Sept. 4, 1936. American Journal of Mathematics, vol. 59, No. 1 (Jan., 1937), pp. 1-8.

Edgett, G. L. Frequency distributions with given statistics which are not all moments. Read Sept. 11, 1931. Metron, vol. 9, No. 2 (Aug., 1931), pp. 2535.

Elconin, Victor. See Michal, A. D.

Emch, Arnold. On the construction of symmetric ruled surfaces. Read Nov. 28, 1936. American Journal of Mathematics, vol. 59, No. 2 (April, 1937), pp. 365-370.

- On certain configurations of points in space and linear systems of surfaces with these as base points. Read Nov. 28, 1936. This Bulletin, vol. 43, No. 4 (April, 1937), pp. 261-265.

- Cremona involutions and covariants connected with the Weddle surface. Read Dec. 29, 1936. Annali di Matematica, vol. 16 (1937), pp. 101-105.

Evans, G. C. Modern methods of analysis in potential theory. Read Sept. 5 and Dec. 31, 1936. This Bulletin, vol. 43, No. 8 (Aug., 1937), pp. 481-502.

Ewing, G. M. Sufficient conditions for a non-regular problem in the calculus of variations. Read Nov. 27, 1936. This Bulletin, vol. 43, No. 6 (June, 1937), pp. 371-376.

Feld, J. M. Configurations inscriptible in a plane cubic curve. Read April 6, 1935. American Mathematical Monthly, vol. 43, No. 9 (Nov., 1936), pp. 549-555.

- Plane cubics invariant under quadratic transformations. Read Feb. 20, 1937. Tôhoku Mathematical Journal, vol. 43, No. 2 (June, 1937), pp. 299303.

Fialkow, A. D. Geometry of dynamical trajectories at a point of equilibrium. Read Oct. 31, 1936. Transactions of this Society, vol. 41, No. 2 (March, 1937), pp. 314-320.

Fisher, R. A. Uncertain inference. Read Aug. 31, 1936. Proceedings of the 
American Academy of Arts and Sciences, vol. 71, No. 4 (Oct., 1936), pp. 245-258.

Flood, M. M. Column normal matric polynomials. Read Feb. 23, 1935 and Dec. 31, 1936. Annals of Mathematics, (2), vol.38, No. 2 (April, 1937), pp. 465468.

The resultant matrix of two polynomials. Read Feb. 29, 1936. American Mathematical Monthly, vol. 44, No. 5 (May, 1937), pp. 309-312; this Bulletin, vol. 43, No. 10 (Oct., 1937), pp. 724-729.

Fort, Tomlinson. The calculus of variations applied to Nörlund's sum. Read Sept. 9, 1937. This Bulletin, vol. 43, No. 12 (Dec., 1937), pp. 885-887.

Frame, J. S. On the numerical determination of tables of characteristics of finite groups. Read Oct. 27, 1934. Tôhoku Mathematical Journal, vol. 42, No. 2 (Dec., 1936), pp. 295-299.

- The degrees of the irreducible components of simply transitive permutation groups. Read Sept. 1, 1936. Duke Mathematical Journal, vol. 3, No. 1 (March, 1937), pp. 8-17.

Franklin, Philip. A new class of transcendental numbers. Read April 10, 1936. Transactions of this Society, vol. 42, No. 2 (Sept., 1937), pp. 155-182.

Friedrichs, Kurt. On certain inequalities and characteristic value problems for analytic functions and for functions of two variables. Read Oct. 31, 1936. Transactions of this Society, vol. 41, No. 3 (May, 1937), pp. 321-364.

Frink, A. H. Distance functions and the metrization problem. Read Sept. 1, 1936. This Bulletin, vol. 43, No. 2 (Feb., 1937), pp. 133-142.

Gergen, J. J. Summability of double Fourier series. Read April 11, 1936. Duke Mathematical Journal, vol. 3, No. 2 (June, 1937), pp. 133-148.

Goldberg, Michael. A class of multi-symmetric polyhedra. Read Oct. 26, 1935. Tôhoku Mathematical Journal, vol. 43, No. 1 (March, 1937), pp. 104-108.

Graustein, W. C. Extensions of the four-vertex theorem. Read Sept. 3, 1936. Transactions of this Society, vol. 41, No. 1 (Jan., 1937), pp. 9-23.

Graustein, W. C., and Jackson, S. B. The four-vertex theorem for a certain type of space curves. Read March 26. 1937. This Bulletin, vol. 43, No. 10 (Oct., 1937), pp. 737-741.

Graves, L. M. On the completing of a Hausdorff space. Read April 10, 1936. Annals of Mathematics, (2), vol. 38, No. 1 (Jan., 1937), pp. 61-64.

- Under-determined systems of linear differential equations. Read Feb. 29, 1936. Tôhoku Mathematical Journal, vol. 43, No. 1 (March, 1937), pp. 178-185.

Grove, C. C. The use of the word "mantissa" in mathematics. Read Sept. 23, 1935. New York, R. C. Coxhead Corp., 1937. 6 pp.

Hall, D. W. On the non-alternating images of linear graphs. Read Feb. 29, 1936. American Journal of Mathematics, vol. 59, No. 3 (July, 1937), pp. 575584.

Hall, Marshall. Divisors of second-order sequences. Read April 20, 1935. This Bulletin, vol. 43, No. 2 (Feb., 1937), pp. 78-80.

- Indices in cubic fields. Read April 19, 1935. This Bulletin, vol. 43, No. 2 (Feb., 1937), pp. 104-108.

Hall, Philip. On the Sylow systems of a soluble group. Read Sept. 5, 1936. Pro- 
ceedings of the London Mathematical Society, (2), vol. 43, Nos. 4-5 (Aug., Sept., 1937), pp. 316-323.

Haller, M. E. Self-projective rational octavics. Read June 18, 1936. Tôhoku Mathematical Journal, vol. 42, No. 1 (June, 1936), pp. 38-53.

Hardy, G. H. The Indian mathematician Ramanujan. Read Aug. 31, 1936. American Mathematical Monthly, vol. 44, No. 3 (March, 1937), pp. 137155.

Harper, F. S. An actuarial study of infant mortality. Read Dec. 1, 1934. Skandinavisk Aktuarietidskrift, vol. 19 (1936), pp. 234-270.

Harrell, E. G. On the topology of a two-parameter, non-metric and non-separable space. I. Read April 10, 1936. Annals of Mathematics, (2), vol. 38, No. 1 (Jan., 1937), pp. 204-211.

Harrold, O. G. On the expansion of the remainder in the open-type Newton-Cotes quadrature formula. Read April 3, 1937. American Journal of Mathematics, vol. 59, No. 2 (April, 1937), pp. 275-289.

Hausmann, B. A., and Ore, Oystein. Theory of quasi-groups. Read March 27, 1937. American Journal of Mathematics, vol. 59, No. 4 (Oct., 1937), pp. 983-1004.

Hestenes, M. R. A direct sufficiency proof for the problem of Bolza in the calculus of variations. Read Nov. 28, 1936. Transactions of this Society, vol. 42, No. 1 (July, 1937), pp. 141-154.

Higdon, R. A., and Holl, D. L. Stresses in moderately thick rectangular plates. Read April 11, 1936. Duke Mathematical Journal, vol. 3, No. 1 (March, 1937), pp. 18-34.

Highberg, I. E. A note on abstract polynomials in complex spaces. Read Nov. 30, 1935. Journal de Mathématiques Pures et Appliquées, vol. 16, No. 3 (Sept., 1937), pp. 307-314.

- See Michal, A. D.; Taylor, A. E.

Highberg, I. E., and Taylor, A. E. An independent set of postulates for abstract linear spaces. Read April 6 and Nov. 30, 1935. Comptes Rendus des Séances de la Société des Sciences et des Lettres de Varsovie, Classe III, vol. 28 (1935), pp. 136-142.

Hille, Einar. A problem in "Factorisatio Numerorum." Read Sept. 5, 1936. Acta Arithmetica, vol. 2 (1936), pp. 134-144.

Holl, D. L. See Higdon, R. A.; Jensen, V. P.

Hollcroft, T. R. The web of quadrics. Read Sept. 5, 1936. This Bulletin, vol. 42, No. 12 (Dec., 1936), pp. 937-944.

- Branch-point manifolds associated with a linear system of primals. Read Sept. 12, 1935. This Bulletin, vol. 43, No. 6 (June, 1937), pp. 379-383.

- - The binet of quadrics in $S_{3}$. Read Sept. 3, 1936. Transactions of this Society, vol. 42, No. 1 (July, 1937), pp. 32-40.

- The existence of algebraic plane curves. Read Feb. 20, 1937. This Bulletin, vol. 43, No. 8 (Aug., 1937), pp. 503-521.

Hopkins, Charles. Concerning uniqueness-bases of finite groups with applications to p-groups of class 2. Read April 11 and Sept. 5, 1936. Transactions of this Society, vol. 41, No. 2 (March, 1937), pp. 287-313.

Hostetter, I. M. An extension of Gibbs' vector analysis to n-space. Read June 18, 
1936. Journal of Mathematics and Physics, Massachusetts Institute of Technology, vol. 15, No. 3 (Nov., 1936), pp. 191-204.

Hotelling, Harold. Relations between two sets of variates. Read Sept. 12, 1935 and June 18, 1936. Biometrika, vol. 28 (1936), pp. 321-377.

Householder, A. S. The dependence of a focal point upon curvature in the calculus of variations. Read Nov. 27, 1936. Contributions to the Calculus of Variations, 1933-37, University of Chicago, pp. 485-526.

Hull, Ralph. Note on the ideals of cyclic algebras. Read April 9, 1937. This Bulletin, vol. 43, No. 6 (June, 1937), pp. 384-387.

Huntington, E. V. Postulates for assertion, conjunction, negation, and equality. Read Sept. 1, 1936. Proceedings of the American Academy of Arts and Sciences, vol. 72, No. 1 (April, 1937), pp. 1-44.

Ingraham, M. H. A note on determinants. Read April 9, 1937. This Bulletin, vol. 43, No. 8 (Aug., 1937), pp. 579-580.

Ingraham, M. H., and Wolf, M. C. Relative linear sets and similarity of matrices whose elements belong to a division algebra. Read Sept. 13, 1935 and Sept. 3, 1936. Transactions of this Society, vol. 42, No. 1 (July, 1937), pp. 16-31.

Ingram, W. H. On the forces occurring in dynamical systems where the obliquity of the coordinate axes varies with the time, with an application to the theory of electrical machinery. Read June 18, 1936. Philosophical Magazine, (7), vol. 23, No. 154 (March, 1937), pp. 475-481.

Iyer, V. G. On effective sets of points in relation to integral functions. Read Sept. 10, 1937. Transactions of this Society, vol. 42, No. 3 (Nov., 1937), pp. 358-365.

Jackson, Dunham. Polynomial approximation on a curve of the fourth degree. Read Dec. 31, 1936. This Bulletin, vol. 43, No. 6 (June, 1937), pp. 388393.

- Orthogonal polynomials on a plane curve. Read Sept. 3, 1936. Duke Mathematical Journal, vol. 3, No. 2 (June, 1937), pp. 228-236.

Jackson, S. B. See Graustein, W. C.

Jacobson, Nathan. A class of normal simple Lie algebras of characteristic zero. Read Dec. 29, 1936. Annals of Mathematics, (2), vol. 38, No. 2 (April, 1937), pp. 508-517.

- A note on non-associative algebras. Read April 10, 1937. Duke Mathematical Journal, vol. 3, No. 3 (Sept., 1937), pp. 544-548.

- Abstract derivation and Lie algebras. Read Dec. 31, 1936. Transactions of this Society, vol. 42, No. 2 (Sept., 1937), pp. 206-224.

- A note on topological fields. Read Sept. 9, 1937. American Journal of Mathematics, vol. 59, No. 4 (Oct., 1937), pp. 889-894.

- p-algebras of exponent p. Read April 10, 1937. This Bulletin, vol. 43, No. 10 (Oct., 1937), pp. 667-670.

Jeffery, R. L. Functions defined by sequences of integrals and the inversion of approximate derived numbers. Read Dec. 27, 1934 and April 20, 1935. Transactions of this Society, vol. 41, No. 2 (March, 1937), pp. 171-192.

Jensen, V. P., and Holl, D. L. An application of derivatives of non-analytic functions in plane stress problems. Read Nov. 28, 1936. This Bulletin, vol. 43, No. 4 (April, 1937), pp. 256-260.

John, Fritz. A representation of Stieltjes integrals by conditionally convergent 
series. Read April 9, 1937. American Journal of Mathematics, vol. 59, No. 2 (April, 1937), pp. 379-384.

- Polar correspondence with respect to a convex region. Read Dec. 31, 1936. Duke Mathematical Journal, vol. 3, No. 2 (June, 1937), pp. 355-369.

Jones, F. B. Concerning certain topologically flat spaces. Read Oct. 28, 1933, June 20,1934, and Feb. 23, 1935. Transactions of this Society, vol. 42, No. 1 (July, 1937), pp. 53-93.

Concerning normal and completely normal spaces. Read Oct. 28, 1933. This Bulletin, vol. 43, No. 10 (Oct., 1937), pp. 671-677.

Kagno, I. N. The triangulation of surfaces and the Heawood color formula. Read April 10, 1936. Journal of Mathematics and Physics, Massachusetts Institute of Technology, vol. 15, No. 3 (Nov., 1936), pp. 179-186.

- The mapping of graphs on surfaces. Read April 19 and Sept. 13, 1935. Journal of Mathematics and Physics, Massachusetts Institute of Technology, vol. 16, No. 1 (Oct., 1937), pp. 46-75.

Kasner, Edward. The geometry of isogonal and equi-tangential series. Read Sept. 9, 1930. Transactions of this Society, vol. 42, No. 1 (July, 1937), pp. 94106.

- The geometry of conformal symmetry (Schwarzian reflexion). Read Sept. 10, 1937. Annals of Mathematics, vol. 38, No. 4 (Oct., 1937), pp. 873-879.

Kasner, Edward, and Comenetz, George. Conformal geometry of horn angles. Read Oct. 26, 1935 and Feb. 29, 1936. Proceedings of the National Academy of Sciences, vol. 22, No. 5 (May, 1936), pp. 303-309.

Kempner, A. J. Anormal systems of numeration. Read Sept. 10, 1935. American Mathematical Monthly, vol. 43, No. 10 (Dec., 1936), pp. 610-617.

Ketchum, P. W. On the expansion of a function analytic at distinct points. Read April 20, 1935. This Bulletin, vol. 43, No. 2 (Feb., 1937), pp. 115-121.

- On the simultaneous expansion of several analytic functions. Read April 11, 1936. Tôhoku Mathematical Journal, vol. 43, No. 2 (June, 1937), pp. 246251.

Kimball, W. S. New basic critical equations and methods in the calculus of variations. Read April 10, 1936. Philosophical Magazine, (7), vol. 23, No. 152 (Jan., 1937), pp. 114-153.

Kleene, S. C. See Church, Alonzo.

Langer, R. E. On the connection formulas and the solutions of the wave equation. Read April 10, 1937. Physical Review, (2), vol. 51, No. 8 (April 15, 1937), pp. 669-676.

- The expansion theory of ordinary differential systems of the first order. Read Sept. 9, 1937. Duke Mathematical Journal, vol. 3, No. 3 (Sept., 1937), pp. 383-393.

Laporte, Otto. Stereographic parameters and pseudo-minimal hypersurfaces. II. Read Sept. 1, 1936. Transactions of this Society, vol. 41, No. 1 (Jan., 1937), pp. 124-137.

Larguier, E. H. On a method for evaluating the moments of a Bernoulli distribution. Read Jan. 2, 1936. Annals of Mathematical Statistics, vol. 7, No. 4 (Dec., 1936), pp. 191-195.

The schools of thought in modern mathematics. Read Feb. 20, 1937. Thought, vol. 12, No. 2 (June, 1937), pp. 225-240. 
Latimer, C. G. The quadratic subfields of a generalized quaternion algebra. Read Sept. 13, 1935. Duke Mathematical Journal, vol. 2, No. 4 (Dec., 1936), pp. 681-684.

The classes of integral sets in a quaternion algebra. Read Dec. 29, 1936. Duke Mathematical Journal, vol. 3, No. 2 (June, 1937), pp. 237-247.

Latshaw, V. V. On second-order adjoint difference systems. Read Dec. 31, 1936. Philosophical Magazine, (7), vol. 23, No. 152 (Jan., 1937), pp. 158-161.

- On fourth order self-adjoint difference systems. Read Oct. 30, 1937. This Bulletin, vol. 43, No. 12 (Dec., 1937), pp. 851-855.

Lefschetz, Solomon. The role of algebra in topology. Read Dec. 30, 1936. This Bulletin, vol. 43, No. 6 (June, 1937), pp. 345-359.

Levi-Civita, Tullio. The relativistic problem of several bodies. Read Sept. 4, 1936. American Journal of Mathematics, vol. 59, No. 1 (Jan., 1937), pp. 9-22. Astronomical consequences of the relativistic two-body problem. Read Sept. 4, 1936. American Journal of Mathematics, vol. 59, No. 2 (April, 1937), pp. 225-234.

Levinson, Norman. On a class of non-vanishing functions. Read Sept. 6, 1934. Proceedings of the London Mathematical Society, (2), vol. 41, No. 5 (June, 1936), pp. 393-407.

Lewis, F. A. Proof of the non-isomorphism of two collineation groups of order 5184. Read June 18, 1936. This Bulletin, vol. 43, No. 10 (Oct., 1937), pp. 742-744.

Lewy, Hans. À priori limitations for solutions of Monge-Ampère equations. II. Read Nov. 28, 1936. Transactions of this Society, vol. 41, No. 3 (May, 1937), pp. 365-374.

Lowan, A. N. On the operational determination of Green's functions in the theory of heat conduction. Read Dec. 31, 1936. Philosophical Magazine, (7), vol. 24, No. 159 (July, 1937), pp. 62-70.

- On some two-dimensional problems in heat conduction. Read Oct. 31, 1936 Philosophical Magazine, (7), vol. 24, No. 161 (Sept., 1937), pp. 410-424.

McCoy, Dorothy. Continuous transformations of finite homogeneous spaces. Read Dec. 28, 1934. National Mathematics Magazine, vol. 10, No. 6 (March, 1936), pp. 212-218.

McCoy, N. H., and Montgomery, Deane. A representation of generalized Boolean rings. Read March 26, 1937. Duke Mathematical Journal, vol. 3, No. 3 (Sept., 1937), pp. 455-459.

McEwen, W. H. An extension of Bernstein's theorem associated with general boundary value problems. Read Sept. 1, 1936. American Journal of Mathematics, vol. 59, No. 2 (April, 1937), pp. 295-305.

McShane, E. J. Semi-continuity of integrals in the calculus of variations. Read Sept. 5, 1936. Duke Mathematical Journal, vol. 2, No. 4 (Dec., 1936), pp. 597-616.

- A navigation problem in the calculus of variations. Read Dec. 29, 1936. American Journal of Mathematics, vol. 59, No. 2 (April, 1937), pp. 327334.

Jensen's inequality. Read Dec. 31, 1936. This Bulletin, vol. 43, No. 8 (Aug., 1937), pp. 521-527.

MacLane, Saunders. A structural characterization of planar combinatorial 
graphs. Read Dec. 30, 1936. Duke Mathematical Journal, vol. 3, No. 3 (Sept., 1937), pp. 460-472.

- A combinatorial condition for planar graphs. Read April 11, 1936. Fundamenta Mathematicae, vol. 28 (1937), pp. 22-32.

- See Adkisson, V. W.

MacNeille, H. M. Partially ordered sets. Read April 19, 1935 and Sept. 5, 1936. Transactions of this Society, vol. 42, No. 3 (Nov., 1937), pp. 416-460.

Mancill, J. D. The minimum of a definite integral with respect to unilateral variations. Read Jan. 2, 1936. Contributions to the Calculus of Variations, 1933-1937, University of Chicago, pp. 85-164.

March, H. W. Bending of a centrally loaded rectangular strip of plywood. Read April 7, 1934. Physics, vol. 7, No. 1 (Jan., 1936), pp. 32-41.

Martin, W. T. Special regions of regularity of functions of several complex variables. Read Jan. 2, 1936. Annals of Mathematics, (2), vol. 38, No. 3 (July, 1937), pp. 602-625.

- See Bochner, Salomon; Wiener, Norbert.

Mears, F. M. Absolute regularity and the Nörlund mean. Read Dec. 27, 1932. Annals of Mathematics, (2), vol. 38, No. 3 (July, 1937), pp. 594-601.

Merriman, G. M. See Walsh, J. L.

Michal, A. D. General tensor analysis. Read April 11, 1936. This Bulletin, vol. 43, No. 6 (June, 1937), pp. 394-401.

Michal, A. D., and Elconin, Victor. Differential properties of abstract transformation groups with abstract parameters. Read Nov. 30, 1935. American Journal of Mathematics, vol. 59, No. 1 (Jan., 1937), pp. 129-143.

- Completely integrable differential equations in abstract spaces. Read June 20, 1934. Acta Mathematica, vol. 68 (1937), pp. 71-107.

Michal, A. D., Highberg, I. E., and Taylor, A. E. Abstract euclidean spaces with independently postulated analytical and geometrical metrics. Read April 6, 1935, Sept. 13, 1935, April 11, 1936, and Sept. 5, 1936. Annali della Reale Scuola Normale Superiore di Pisa, (2), vol. 6, No. 2 (April, 1937), pp. 117-148.

Miller, E. W. Concerning biconnected sets. Read April 9, 1937. Fundamenta Mathematicae, vol. 29 (1937), pp. 123-133.

Montgomery, Deane. Pointwise periodic homeomorphisms. Read June 18, 1936. American Journal of Mathematics, vol. 59, No. 1 (Jan., 1937), pp. 118120.

- Almost periodic transformation groups. Read Feb. 20, 1937. Transactions of this Society, vol. 42, No. 2 (Sept., 1937), pp. 322-332.

- See McCoy, N. H.

Montgomery, Deane, and Zippin, Leo. Translation groups of three-space. Read Jan. 1, 1936. American Journal of Mathematics, vol. 49, No. 1 (Jan., 1937), pp. 121-128.

Moore, C. N. Convergence factors for double series summable by Nörlund means. Read Nov. 29, 1935. Proceedings of the National Academy of Sciences, vol. 22, No. 3 (March, 1936), pp. 167-170.

Moore, R. L. Concerning essential continua of condensation. Read Jan. 2, 1936. Transactions of this Society, vol. 42, No. 1 (July, 1937), pp. 41-52. 
Moritz, R. E. Note on Taylor's theorem. Read June 18, 1936. American Mathematical Monthly, vol. 44, No. 1 (Jan., 1937), pp. 31-33.

Morse, A. P. Convergence in variation and related topics. Read Oct. 31, 1936. Transactions of this Society, vol. 41, No. 1 (Jan., 1937), pp. 48-83. See Adams, C. R.

Morse, Marston. Functional topology and abstract variational theory. Read April 11, 1936. Proceedings of the National Academy of Sciences, vol. 22, No. 5 (May, 1936), pp. 313-319.

- Functional topology and abstract variational theory. Read Dec. 31, 1936. Annals of Mathematics, (2), vol. 38, No. 2 (April, 1937), pp. 386-449.

Murnaghan, F. D. Finite deformations of an elastic solid. Read Sept. 3, 1936. American Journal of Mathematics, vol. 59, No. 2 (April, 1937), pp. 235260.

Murray, F. J. On complementary manifolds and projections in spaces $L_{p}$ and $l_{p}$. Read Sept. 5, 1936. Transactions of this Society, vol. 41, No. 1 (Jan., 1937), pp. $138-152$.

Murray, F. J., and von Neumann, John. On rings of operators. II. Read Oct. 31, 1936. Transactions of this Society, vol. 41, No. 2 (March, 1937), pp. 208248.

Myers, S. B. Adjoint systems in the problem of Mayer under general end-conditions. Read April 3, 1931. This Bulletin, vol. 38, No. 4 (April, 1932), pp. 303-312.

- Connections between differential geometry and topology. I: Simply connected surfaces. Read Dec. 28, 1934. Duke Mathematical Journal, vol. 1, No. 3 (Sept., 1935), pp. 376-391.

Neikirk, L. I. Some symbolic identities. Read June 18, 1936. This Bulletin, vol. 43, No. 12 (Dec., 1937), pp. 848-851.

von Neumann, John. See Murray, F. J.

Nichols, G. D. A generalized element of decomposition for doubly periodic functions. Read April 11, 1936. This Bulletin, vol. 43, No. 4 (April, 1937), pp. 249-252.

Norris, Nilan. Convexity properties of generalized mean value functions. Read Jan. 2, 1936. Annals of Mathematical Statistics, vol. 8, No. 2 (June, 1937), pp. 118-120.

Northrop, E. P. Note on a singular integral. II. Read Jan. 2, 1936. Duke Mathematical Journal, vol. 2, No. 4 (Dec., 1936), pp. 617-625.

Oakley, C. O. Sur les équations semilinéaires et leurs configurations géométriques. Read Jan. 1, 1936. Bulletin Scientifique de l'École Polytechnique de Timisoura, Roumainie, vol. 7 (1937), pp. 1-11.

Oldenburger, Rufus. Equivalence of multilinear forms singular on one index. Read Dec. 28, 1934. Duke Mathematical Journal, vol. 2, No. 4 (Dec., 1936), pp. 671-680.

- Real canonical binary trilinear forms. Read Dec. 29, 1936. American Journal of Mathematics, vol. 59, No. 2 (April, 1937), pp. 427-435.

_- Real canonical binary symmetric trilinear forms. Read March 26, 1937. This Bulletin, vol. 43, No. 8 (Aug., 1937), pp. 546-553.

Olds, C. D. On the remainder in the approximate evaluation of the probability in 
the symmetrical case of James Bernoulli's theorem. Read April 3, 1937. This Bulletin, vol. 43, No. 12 (Dec., 1937), pp. 806-812.

Ore, Oystein. On the theorem of Jordan-Hölder. Read Sept. 5, 1936. Transactions of this Society, vol. 41, No. 2 (March, 1937), pp. 266-275.

- Structures and group theory. I. Read Dec. 31, 1936. Duke Mathematical Journal, vol. 3, No. 2 (June, 1937), pp. 149-174.

See Hausmann, B. A.

Oxtoby, J. C. The category and Borel class of certain subsets of $\mathcal{L}_{p}$. Read Sept. 5, 1936. This Bulletin, vol. 43, No. 4 (April, 1937), pp. 245-248.

Pall, Gordon. The quaternion congruence $\bar{t} a t=b(\bmod g)$ and the equation $h(8 n+1)=x^{2}+y^{2}+z^{2}$. Read Sept. 10, 1937. American Journal of Mathematics, vol. 59, No. 4 (Oct., 1937), pp. 895-913.

Parker, W. V. The characteristic roots of a matrix. Read Sept. 10, 1937. Duke Mathematical Journal, vol. 3, No. 3 (Sept., 1937), pp. 484-487.

On symmetric determinants. Read Sept. 10, 1937. This Bulletin, vol. 43, No. 10 (Oct., 1937), pp. 730-732.

Phalen, H. R. Le proprietà metriche della quadrica di Moutard. Read April 6, 1928. Annali di Matematica, vol. 13 (1935), pp. 37-40.

Poritsky, Hillel. Thermal stresses in cylindrical tubes. Read Sept. 5, 1936. Philosophical Magazine, (7), vol. 24, No. 160 (Aug., 1937), pp. 209-223.

- On reftection of singularities of harmonic functions corresponding to the boundary condition $\partial u / \partial n+a u=0$. Read Sept. 5, 1934. This Bulletin, vol. 43, No. 12 (Dec., 1937), pp. 873-884.

Post, E. L. Finite combinatory processes-Formulation 1. Read Oct. 31, 1936. Journal of Symbolic Logic, vol. 1, No. 3 (Sept., 1936), pp. 103-105.

Price, G. B. On the extreme points of convex sets. Read Oct. 31, 1936. Duke Mathematical Journal, vol. 3, No. 1 (March, 1937), pp. 56-67.

Rademacher, H. A. A convergent series for the partition function $p(n)$. Read Feb. 20, 1937. Proceedings of the National Academy of Sciences, vol. 23, No. 2 (Feb., 1937), pp. 78-84.

On the partition function. Read Dec. 31, 1936. Proceedings of the London Mathematical Society, (2), vol. 43, No. 4 (Aug., 1937), pp. 241-254.

Radó, Tibor. Solution of a problem of $R$. Riesz on the harmonic majorants of subharmonic functions. Read Dec. 31, 1936. Duke Mathematical Journal, vol. 3, No. 1 (March, 1937), pp. 123-132.

Rainich, G. Y. See Boggs, Herbert.

Randels, W. C. On the summability of Fourier series. Read Jan. 2 and April 10, 1936. Transactions of this Society, vol. 41, No. 1 (Jan., 1937), pp. 24-47.

Rechard, O. H. The expansion problem associated with a class of irregular ordinary differential boundary value problems. Read Nov. 29, 1930. University of Wyoming Publications, vol. 2, No. 10 (Dec., 1936), pp. 181-210.

Reid, W. T. Sufficient conditions by expansion methods for the problem of Bolza in the calculus of variations. Read Sept. 10, 1935. Annals of Mathematics, (2), vol. 38, No. 3 (July, 1937), pp. 662-678.

$A$ direct expansion proof of sufficient conditions for the non-parametric problem of Bolza. Read April 10, 1937. Transactions of this Society, vol. 42, No. 2 (Sept., 1937), pp. 183-190. 
Boundary value problems of the calculus of variations. Read April 9, 1937. This Bulletin, vol. 43, No. 10 (Oct., 1937), pp. 633-666.

Rietz, H. L. On the frequency distributions of certain ratios. Read Sept. 12, 1935 Annals of Mathematical Statistics, vol. 7, No. 3 (Sept., 1936), 145-153.

- Some topics in sampling theory. Read Nov. 27, 1936. This Bulletin, vol. 43, No. 4 (April, 1937), pp. 209-230.

Riordan, John. Moment recurrence relations for binomial, Poisson and hypergeometric frequency distributions. Read Sept. 3, 1936. Annals of Mathematical Statistics, vol. 8, No. 2 (June, 1937), pp. 103-111.

Robbins, H. E. On a class of recurrent sequences. Read Sept. 1, 1936. This Bulletin, vol. 43, No. 6 (June, 1937), pp. 413-417.

Robertson, M. S. On the order of the coefficients of a univalent function. Read April 11, 1936. American Journal of Mathematics, vol. 59, No. 1 (Jan., 1937), pp. 205-210.

- On the summability by positive typical means of sequences $\{f(n \theta)\}$. Read April 11, 1936. This Bulletin, vol. 43, No. 4 (April, 1937), pp. 287-292.

- A representation of all analytic functions in terms of functions with positive real part. Read Dec. 30, 1936. Annals of Mathematics, (2), vol. 38, No. 4 (Oct., 1937), pp. 770-783.

Robinson, G. de B. On the fundamental region of an orthogonal representation of a finite group. Read Sept. 10, 1935. Proceedings of the London Mathematical Society, (2), vol. 43, No. 4 (Aug., 1937), pp. 289-301.

Robinson, L. B. Une pseudo-fonction de l'équation d'Izumi. Read Feb. 29, 1936. Bulletin de la Société Mathématique de France, vol. 64 (1936), pp. 66-70.

- Complément à une étude sur l'équation d' Izumi. Read Feb. 29, 1936. Bulletin de la Société Mathématique de France, vol. 64 (1936), pp. 213-215.

- A functional equation satisfied by a lacunary function. Read April 11, 1936. Comptes Rendus de l'Académie des Sciences de l'URSS, vol. 12 (1936), pp. 247-249.

- A system of Riquier and the tensor calculus. Read March 27, 1937. Comptes Rendus de l'Académie des Sciences de l'URSS, vol. 15, No. 8 (June, 1937), pp. 411-414.

- On the equation of Izumi having a singular solution holomorphic except at the origin and a lacunary general solution. Read Sept. 5, 1934. Tôhoku Mathematical Journal, vol. 43, No. 2 (June, 1937), pp. 310-313.

Robinson, Robin. A condition in invariant form for a net without detours. Read Sept. 3, 1936. This Bulletin, vol. 43, No. 2 (Feb., 1937), pp. 102-104.

Robinson, R. M. The theory of classes. A modification of von Neumann's system. Read Sept. 5, 1936. Journal of Symbolic Logic, vol. 2, No. 1 (March, 1937), pp. 29-36.

Roever, W. H. A geometric representation of a line integral. Read Dec. 1, 1928. American Mathematical Monthly, vol. 44, No. 1 (Jan., 1937), pp. 22-24.

- Meaning and function of a picture. Read April 9, 1937. American Mathematical Monthly, vol. 44, No. 8 (Oct., 1937), pp. 521-523.

Rosser, J. B. Gödel theorems for non-constructive logics. Read Dec. 31, 1936. Journal of Symbolic Logic, vol. 2, No. 3 (Sept., 1937), pp. 129-137.

Roth, W. E. On certain matrices and their determinants. Read April 9, 1937. This Bulletin, vol. 43, No. 12 (Dec., 1937), pp. 856-861. 
Russell, H. N. Model stars. Read Oct. 31, 1936. This Bulletin, vol. 43, No. 2 (Feb., 1937), pp. 49-77.

Sagen, O. K. The integers represented by sets of positive ternary quadratic nonclassic forms. Read April 6, 1934. American Journal of Mathematics, vol. 59, No. 1 (Jan., 1937), pp. 33-42.

Saks, Stanislaw. On some functionals. II. Read Sept. 5, 1936. Transactions of this Society, vol. 41, No. 1 (Jan., 1937), pp. 160-170.

Schaeffer, A. C. Existence theorem for the flow of an ideal incompressible fluid in two dimensions. Read Sept. 10, 1937. Transactions of this Society, vol. 42, No. 3 (Nov., 1937), pp. 497-513.

Schoenberg, I. J. Regular simplices and quadratic forms. Read April 11, 1936. Journal of the London Mathematical Society, vol. 12, No. 1 (Jan., 1937), pp. 48-55.

- On certain metric spaces arising from euclidean spaces by a change of metric and their imbedding in Hilbert space. Read Feb. 20, 1937. Annals of Mathematics, (2), vol. 38, No. 4 (Oct., 1937), pp. 787-793.

Sewell, W. E. Generalized derivatives and approximation by polynomials. Read Dec. 27, 1934 and Dec. 31, 1935. Transactions of this Society, vol. 41, No. 1 (Jan., 1937), pp. 84-123.

- $A$ note on the relation between integral and Tchebycheff approximation by polynomials in the complex domain. Read Dec. 31, 1936. This Bulletin, vol. 43, No. 6 (June, 1937), pp. 425-431. See Walsh, J. L.

Shaw, A. A. On measures and weights by Epiphanius. Read June 18, 1936. National Mathematics Magazine, vol. 11, No. 1 (Oct., 1936), pp. 3-7.

Sheffer, I. M. A simplified solution of equation $\Delta y(x)=F(x)$. Read Sept. 5, 1936. This Bulletin, vol. 43, No. 4 (April, 1937), pp. 283-287.

Shohat, J. A. On the convergence properties of Lagrange interpolation based on the zeros of orthogonal Tchebycheff polynomials. Read March 27, 1937. Annals of Mathematics, (2), vol. 38, No. 4 (Oct., 1937), pp. 758-769.

- On mechanical quadratures, in particular, with positive coefficients. Read Feb. 23, 1935 and Oct. 29, 1935. Transactions of this Society, vol. 42, No. 3 (Nov., 1937), pp. 461-496.

Silverman, L. L. Products of Nörlund transformations. Read Sept. 3, 1936. This Bulletin, vol. 43, No. 2 (Feb., 1937), pp. 95-101.

Sinkov, Abraham. Necessary and sufficient conditions for generating certain simple groups by two operators of periods 2 and 3. Read Oct. 26, 1935 and Feb. 29, 1936. American Journal of Mathematics, vol. 59, No. 1 (Jan., 1937), pp. $67-76$.

On the group defining relations $(2,3,7 ; p)$. Read April 11, 1936. Annals of Mathematics, (2), vol. 38, No. 3 (July, 1937), pp. 577-584.

Snyder, Virgil, and Carroll-Rusk, E. A series of involutorial Cremona transformations in $S_{n}$ belonging multiply to a non-linear line complex. Read March 27, 1937. American Journal of Mathematics, vol. 59, No. 4 (Oct., 1937), pp. 775-782.

Staniland, A. E. Analytic affine transformations in euclidean space of $2 n$ dimensions. Read Sept. 3, 1936. Journal of Mathematics and Physics, Massachusetts Institute of Technology, vol. 15, No. 4 (Dec., 1936), pp. 283-290. 
Stoker, J. J. Über die Gestalt der positiv gekrilmmten offenen Flächen im dreidimensionalen Raume. Read Nov. 30, 1935. Compositio Mathematica, vol. 3, No. 1 (June, 1936), pp. 55-89.

Stone, M. H. Applications of the theory of Boolean rings to general topology. Read Sept. 5, 1936. Transactions of this Society, vol. 41, No. 3 (May, 1937), pp. 375-481.

Stopher, E. C. Cyclic relations in point set theory. Read April 10, 1937. This Bulletin, vol. 43, No. 10 (Oct., 1937), pp. 686-694.

Sugar, Alvin. A new universal Waring theorem for eighth powers. Read Nov. 30, 1935. This Bulletin, vol. 41, No. 10 (Oct., 1935), pp. 675-678.

- A note on James' asymptotic Waring theorem for the cubic polynomial. Read Dec. 31, 1936. Dissertation, California, 1936.

- Ideal Waring theorem for the polynomial $m\left(x^{3}-x\right) / 6-m\left(x^{2}-x\right) / 2+x$. Read Sept. 5, 1936. American Journal of Mathematics, vol. 59, No. 1 (Jan., 1937), pp. 43-49.

Synge, J. L. Tensorial methods in dynamics. Read Dec. 31, 1935. University of Toronto Studies, Applied Mathematics Series, No. 2 (1936), 38 pp.

Szász, Otto. On the partial sums of certain Fourier series. Read April 10, 1937. American Journal of Mathematics, vol. 59, No. 3 (July, 1937), pp. 696708.

- Fourier series and mean moduli of continuity. Read Dec. 31, 1936. Transactions of this Society, vol. 42, No. 3 (Nov., 1937), pp. 366-395.

Taussky, Olga. A remark on unramified class fields. Read Dec. 28, 1934. Journal of the London Mathematical Society, vol. 12, No. 2 (April, 1937), pp. 86-88.

Taylor, A. E. Analytic functions in general analysis. Read Nov. 30, 1935 and Sept. 1, 1936. Paris Comptes Rendus, vol. 203, No. 23 (Dec., 1936), pp. 1228-1230.

- A theory of integral invariants. Read Dec. 1, 1934. Journal de Mathematiques Pures et Appliquées, vol. 16, No. 1 (March, 1937), pp. 15-41.

- Analytic functions in general analysis. II. Read April 11, 1936. Annali della Reale Scuola Normale Superiore di Pisa, (2), vol. 6, Nos. 3-4 (Sept., 1937), pp. 277-292.

See Highberg, I. E.; Michal, A. D.

Taylor, A. E., and Highberg, I. E. On postulate systems for normed vector spaces. Read Nov. 30, 1935. Comptes Rendus des Séances de la Société des Sciences et des Lettres de Varsovie, Classe III, vol. 28 (1935), pp. 142-153.

Thielman, H. P. A generalization of trigonometry. Read April 9, 1937. National Mathematics Magazine, vol. 11, No. 8 (May, 1937), pp. 349-351.

Thomas, T. Y. Riemann spaces of class one and their characterization. Read Sept. 5, 1936. Acta Mathematica, vol. 67, No. 3 (Aug., 1936), pp. 169-211.

- Fields of parallel vectors in the large. Read Sept. 5, 1936. Compositio Mathematica, vol. 3, No. 3 (Aug., 1936), pp. 453-468.

- Arcs in affinely connected spaces. Read Sept. 5, 1936. Annals of Mathematics, (2), vol. 38, No. 1 (Jan., 1937), pp. 120-130.

Thompson, W. R. On confidence ranges for the median and other expectation distributions for populations of unknown distribution form. Read Oct. 26, 1935. 
Annals of Mathematical Statistics, vol. 7, No. 3 (Sept., 1936), pp. 122128.

Torrance, C. C. Tangent lines and planes in topological spaces. Read Sept. 12, 1935. Transactions of this Society, vol. 41, No. 2 (March, 1937), pp. 193207.

Traber, R. E. A fundamental lemma on normal coordinates and its applications. Read Dec. 29, 1936. Quarterly Journal of Mathematics, vol. 8, No. 30 (June, 1937), pp. 142-147.

Trjitzinsky, W. J. Non-linear difference equations. Read Sept. 1, 1936. Compositio Mathematica, vol. 5, No. 1 (Sept., 1937), pp. 1-66.

— Theory of non-linear singular differential systems. Read Sept. 9, 1937. Transactions of this Society, vol. 42, No. 2 (Sept., 1937), pp. 225-321.

Turpin, W. S. On the fundamental group of a certain class of plane algebraic curves. Read April 11, 1936. American Journal of Mathematics, vol. 59, No. 3 (July, 1937), pp. 529-544.

- Concerning special centers of projection for an algebraic space branch. Read April 11, 1936. This Bulletin, vol. 43, No. 10 (Oct., 1937), pp. 697-702.

Wall, H. S. Hypergroups. Read Dec. 28, 1934 and Sept. 5, 1936. American Journal of Mathematics, vol. 59, No. 1 (Jan., 1937), pp. 77-98.

Walsh, J. L. On the shape of level curves of Green's function. Read Dec. 31, 1936. Proceedings of the National Academy of Sciences, vol. 23, No. 2 (Feb., 1937), pp. 84-89; American Mathematical Monthly, vol. 44, No. 4 (April, 1937), pp. 202-213.

Walsh, J. L., and Merriman, G. M. Note on the simultaneous orthogonality of harmonic polynomials on several curves. Read Dec. 31, 1936. Duke Mathematical Journal, vol. 3, No. 2 (June, 1937), pp. 279-288.

Walsh, J. L., and Sewell, W. E. Note on degree of approximation to an integral by Riemann sums. Read Dec. 30, 1936. American Mathematical Monthly, vol. 44, No. 3 (March, 1937), pp. 155-160.

Note on the relation between continuity and degree of polynomial approximation in the complex domain. Read March 27, 1937. This Bulletin, vol. 43, No. 8 (Aug., 1937), pp. 557-563.

Ward, Morgan. Linear divisibility sequences. Read June 18, 1936. Transactions of this Society, vol. 41, No. 2 (March, 1937), pp. 276-286.

- Arithmetic functions on rings. Read Sept. 1, 1936. Annals of Mathematics, (2), vol. 38, No. 3 (July, 1937), pp. 725-732.

Wardwell, J. F. Non-separating transformations. Read April 10, 1936. Duke Mathematical Journal, vol. 2, No. 4 (Dec., 1936), pp. 745-750.

Warnock, W. G. A note on line configurations. Read Sept. 13, 1935. Tôhoku Mathematical Journal, vol. 43, No. 1 (March, 1937), pp. 74-76.

Webster, M. S. On the zeros of Jacobi polynomials with applications. Read April 20, 1935. Duke Mathematical Journal, vol. 3, No. 3 (Sept., 1937), pp. 426442.

Weisner, Louis. Criteria for the compositeness of finite groups. Read Oct. 26, 1935. Duke Mathematical Journal, vol. 2, No. 4 (Dec., 1936), pp. 691-697.

Wheeler, C. H. A type of homogeneity for continuous curves. Read June 22, 1933. American Journal of Mathematics, vol. 59, No. 2 (April, 1937), pp. 315326. 
Whiteman, A. L. Postulates for Boolean algebra in terms of ternary rejection. Read Dec. 31, 1936. This Bulletin, vol. 43, No. 4 (April, 1937), pp. 293298.

- On a theorem of higher reciprocity. Read Feb. 20, 1937. This Bulletin, vol. 43, No. 8 (Aug., 1937), pp. 567-572.

Whitney, Hassler. The imbedding of manifolds in families of analytic manifolds. Read Sept. 4, 1934. Annals of Mathematics, vol. 37, No. 4 (Oct., 1936), pp. 865-878.

- On regular closed curves in the plane. Read Sept. 5, 1936. Compositio Mathematica, vol. 4, No. 2 (March, 1937), pp. 276-284.

- - Matrices of integers and combinatorial topology. Read Dec. 31, 1936. Duke Mathematical Journal, vol. 3, No. 1 (March, 1937), pp. 35-45.

- - On the maps of an n-sphere into another n-sphere. Read Oct. 31, 1936. Duke Mathematical Journal, vol. 3, No. 1 (March, 1937), pp. 46-50.

- The maps of an n-complex into an n-sphere. Read Oct. 26, 1935. Duke Mathematical Journal, vol. 3, No. 1 (March, 1937), pp. 51-55.

- On products in a complex. Read March 27, 1937. Proceedings of the National Academy of Sciences, vol. 23, No. 5 (May, 1937), pp. 285-291.

- Analytic coordinate systems and arcs in a manifold. Read March 27, 1937. Annals of Mathematics, (2), vol. 38, No. 4 (Oct., 1937), pp. 809-818.

- Topological properties of differentiable manifolds. Read Sept. 9, 1937. This Bulletin, vol. 43, No. 12 (Dec., 1937), pp. 785-805.

- A numerical equivalent of the four color map problem. Read Dec. 26, 1933. Monatshefte für Mathematik und Physik, vol. 45, No. 3 (1937), pp. 207213.

Whyburn, G. T. Semi-closed sets and collections. Read Sept. 1, 1936. Duke Mathematical Journal, vol. 2, No. 4 (Dec., 1936), pp. 685-690.

- Concerning rationality bases for curves. Read Sept. 13, 1935. Ergebnisse eines Mathematischen Kolloquiums, Wien, vol. 7 (1936), pp. 58-60.

- Interior transformations on compact sets. Read March 27, 1937. Duke Mathematical Journal, vol. 3, No. 2 (June, 1937), pp. 370-381.

Whyburn, Lucille. Rotation groups around a set of fixed points. Read Sept. 12, 1935. Fundamenta Mathematicae, vol. 28 (1937), pp. 124-130.

Widder, D. V. The successive iterates of the Stieltjes kernel expressed in terms of the elementary functions. Read Sept. 10, 1937. This Bulletin, vol. 43, No. 12 (Dec., 1937), pp. 813-817.

Wiener, Norbert, and Martin, W. T. Taylor's series of entire functions of smooth growth. Read Dec. 31, 1936. Duke Mathematical Journal, vol. 3, No. 2 (June, 1937), pp. 213-223.

Williamson, John. The conjunctive equivalence of pencils of hermitian and antihermitian matrices. Read March 26, 1937. American Journal of Mathematics, vol. 59, No. 2 (April, 1937), pp. 399-413.

Wolf, M. C. Symmetric functions of non-commutative elements. Read Sept. 10, 1935. Duke Mathematical Journal, vol. 2, No. 4 (Dec., 1936), pp. 626637.

See Ingraham, M. H.

Woodard, D. W. The characterization of the closed n-cell. Read June 20, 1934. Transactions of this Society, vol. 42, No. 3 (Nov., 1937), pp. 396-415. 
Wren, F. L. Neo-Sylvester contractions and the solution of systems of linear equations. Read Dec. 29, 1936. This Bulletin, vol. 43, No. 12 (Dec., 1937), pp. 823-834.

Zariski, Oscar. Generalized weight properties of the resultant of $n+1$ polynomials in $n$ indeterminates. Read Dec. 31, 1936. Transactions of this Society, vol. 41 , No. 2 (March, 1937), pp. 249-265.

- The topological discriminant group of a Riemann surface of genus $p$. Read Dec. 31, 1936. American Journal of Mathematics, vol. 59, No. 2 (April, 1937), pp. 335-358.

Zippin, Leo. See Montgomery, Deane.

Zorn, Max. p-adic analysis and elementary number theory. Read Oct. 26, 1935. Annals of Mathematics, (2), vol. 38, No. 2 (April, 1937), pp. 451-464.

- On a theorem of Engel. Read June 18, 1936. This Bulletin, vol. 43, No. 6 (June, 1937), pp. 401-404. 